\title{
Implementation of Project-Based Learning (PjBL) Assisted by E-Learning through Lesson Study Activities to Improve the Quality of Learning in Physics Learning Planning Courses
}

\author{
Sri Wahyu Widyaningsih ${ }^{1} \& \operatorname{Irfan}_{\text {Yusuf }^{1}}$ \\ ${ }^{1}$ Department of Physics Education, University of Papua, Indonesia \\ Correspondence: Irfan Yusuf, Department of Physics Education, University of Papua, Manokwari 98314 West Papua, \\ Indonesia. E-mail: i.yusuf@unipa.ac.id
}

Received: October 4, 2019

Accepted: November 12, 2019

Online Published: November 13, 2019

doi:10.5430/ijhe.v9n1p60

URL: https://doi.org/10.5430/ijhe.v9n1p60

\begin{abstract}
This study aims to improve the quality of learning in physics learning planning courses through the implementation of Project-Based Learning (PjBL) assisted by E-Learning through Lesson Study activities. This was qualitative research through the stages of Lesson Study activities. Subjects in this study were the 5th-semester students who program 11 physics learning planning subjects in the 2018-2019 academic year in the Department of Physics Education, University of Papua. The research data were obtained through the learning outcomes of student tests. The instrument was given after the submission of each topic of study, observation sheet of student activities, interview guidelines, documentation in the form of video recordings during open class implementation, and student response questionnaire. Data were analyzed through Rasch modeling with the help of the Winstep application to analyze student responses after learning. Lesson Study activities consist of three phases of activities, namely Plan, Do, and See. In the Planning stage, discussions with the team of lecturers were held to develop the Chapter Design and Lesson Plan. In the Do stage, the model lecturer was based on the tools that have been prepared. In the See stage, the reflection was carried to find out weaknesses and strengths during learning, which was then followed up on further learning. The results showed that student-learning outcomes increased student responses to good learning, and the learning atmosphere seemed very fun. Therefore, it could be concluded that the implementation of PjBL assisted E-Learning through Lesson Study activities can improve the quality of learning in physics learning planning subjects.
\end{abstract}

Keywords: e-learning, learning outcomes, lesson study, PjBL

\section{Introduction}

All levels of education, including universities, need to apply innovative learning to develop the quality of learning. Students need to be provided with a good understanding before they enter the world of work (Karyadi, Sinon, Yusuf, \& Widyaningsih, 2018). Especially for prospective teacher students who will teach at the school. Every subject needs to be well understood by students. Students in the Department of Physics Education, University of Papua, have to enroll in a physics learning planning course. The course is one of the subjects that is very important to equip students with insight regarding developing learning tools before they teach. The materials are currently delivered through the lecturing method, where lecturer directly presents the subject matter without involving the student's activities to find and find the solution to the problem itself. Student learning outcomes are also lacking. This is due to their limited ability to develop their knowledge from lecturers (Widyaningsih \& Yusuf, 2018).

Lecturers can use information and communication technology as a source of learning (Kurniawan, Mujasam, Yusuf, \& Widyaningsih, 2019; Skultety, Gonzalez, \& Vargas, 2017). Although information and communication technology media can be applied in learning, it does not mean that the media replace the lecturer (Yusuf \& Widyaningsih, 2019). However, the role of the lecturer's shifts from learning resources to facilitators, meaning that lecturers must be able to facilitate students to practice critical thinking, collaborate, and communicate through the information and communication technology media (Cochrane, Redmond, \& Corrin, 2018; Yusuf \& Subaer, 2013). In learning interactions, students do not always have to be trained; they can search, find, solve problems and train themselves. The ability of each student is also different; some students have high abilities so that they can search, find and develop themselves. However, some students still need assistance to understand the subject matter. 
A model of learning that can improve student learning outcomes is Project-Based Learning (PjBL) with e-learning integration. $\mathrm{PjBL}$ is learning that is designed for complex problems, in which students conduct investigations to understand it, emphasizing learning with long-standing activities, the tasks given to students are multidisciplinary and product-oriented (Barron et al., 1998; Baş \& Beyhan, 2010). The use of e-learning in PjBL is intended to provide learning facilities for students because each material and assignment can be accessed online whenever and wherever they are (Heo, Lim, \& Kim, 2010; Koh, Herring, \& Hew, 2010). The e-learning program used in this lecture is the Google Classroom program. Google Classroom provides various facilities such as online discussions, posting lecture material, and assigning online assignments to students (Alverson, Schwartz, Libraries, \& 2018, 2019; Heggart, Yoo, $\&$ Heggart, 2018). To improve the effectiveness of learning, in this study, PjBL learning is assisted by e-learning through application of lesson study activities. The lesson study activities involve model lecturers and observers to obtain reflections in the form of suggestions and criticisms that can be used as a consideration for the implementation of learning activities (Skultety et al., 2017). Lesson study is a means for teachers to collaborate in finding solutions and designing innovative and learner-centered learning (Sarimanah, 2018). Therefore, it is hoped that the implementation of PjBL with the help of e-learning through lesson study activities can improve the quality of learning.

\section{Method}

This was a qualitative research through the stages of lesson study activities. The lesson study activities in this study were carried out in three stages of activities namely Plan, Do, and See (C. Fernandez \& Yoshida, 2004). In the Plan stage, discussions with the team of lecturers were held to develop chapter design and lesson plans. In the Do stage, the model lecturer based on the tools that have been prepared does learning. In the See stage, the reflection was carried out to find out weaknesses and strengths during learning, which is then followed up on further learning. The meeting was held for four times. At each meeting, lesson study activities were conducted to obtain information regarding the learning atmosphere.

Subjects in this study were the 5th-semester students who program 11 Physics Learning Planning Subjects in the 2018-2019 academic year. Research data were assessment of student learning outcomes obtained through project assignments given in each meeting. Project tasks undertaken by students collected online through the Google Classroom application. Assessment of student learning outcomes was carried out online through the Google Classroom application - category analysis of student learning outcomes as in Table I (Riduwan, 2011).

Table 1. Assessment category of student learning outcomes

\begin{tabular}{cc}
\hline Interval class & Category \\
\hline $81-100$ & Very good \\
$61-80$ & Good \\
$41-60$ & Medium \\
$21-40$ & Less \\
$<21$ & Very less \\
\hline
\end{tabular}

In the implementation of classroom learning, student activities were observed through observation sheets filled by observers. Other research data were also obtained through documentation of activities in the form of video recordings during the implementation of the open class. To obtain student responses during learning, a student response questionnaire can be provided online through the Google Classroom application. The results of the assessment of student responses were analyzed through Rasch modeling with the help of the Ministep application.

\section{Results and Discussion}

This research activity was carried out four times the lesson study activities. The model lecturer carries out learning activities and observed by observers. The details of the lesson study activities can be seen in Table 2 . 
Table 2. Details of lesson study activities

\begin{tabular}{cccccc}
\hline Lesson to & Subject matter & $\begin{array}{c}\text { Model } \\
\text { Lecturer }\end{array}$ & Observer & Plan & Implementation Time \\
\hline 1 & KKM analysis & Widya & Halima, Nurul, & Friday, August 31, 2018 & Monday, September 3, \\
& & & Irfan & 2018 \\
2 & Effective Week & Widya & Halima, Nurul, & Friday, August 7, 2018 & Monday, September 10, \\
& Analysis & & Irfan & 2018 \\
3 & Annual Program & Widya & Halima, Nurul, & Friday, August 14, 2018 & Monday, September 17, \\
& Analysis & & Irfan & 2018 \\
& Semester Program & Widya & Halima, Adonia, & Friday, August 21, 2018 & Monday, September 24, \\
& Analysis & & Irfan & & 2018
\end{tabular}

The implementation of learning is carried out through PjBL learning stages. In general, PjBL has steps or guides called planning, creating, and processing (Genc, 2015). PjBL is comprehensive learning that includes students conducting collaborative investigations. PjBL helps students in learning through assigned tasks (Widyaningsih \& Yusuf, 2018). At each meeting, lesson study activities were conducted to improve the quality of learning.

\subsection{Lesson 1}

\subsubsection{Plan Phase}

At the first meeting, the material taught was about determining the value of the Minimum Completeness Criteria (KKM). During the Plan phase, discussions were held with a team of lecturers of Physics Education to develop Chapter Design and Lesson Plan. Lecturers prepare presentation media in the form of powerpoint slides, examples of KKM analysis, and KKM analysis worksheets using excel programs.

\subsubsection{Do Phase}

At the beginning of the lecture, the model lecturer gave a general description of the material and provided motivation and apperception about the material analyzing the KKM. Figure 1 shows the learning atmosphere when the model lecturer presents introductory material on KKM analysis.

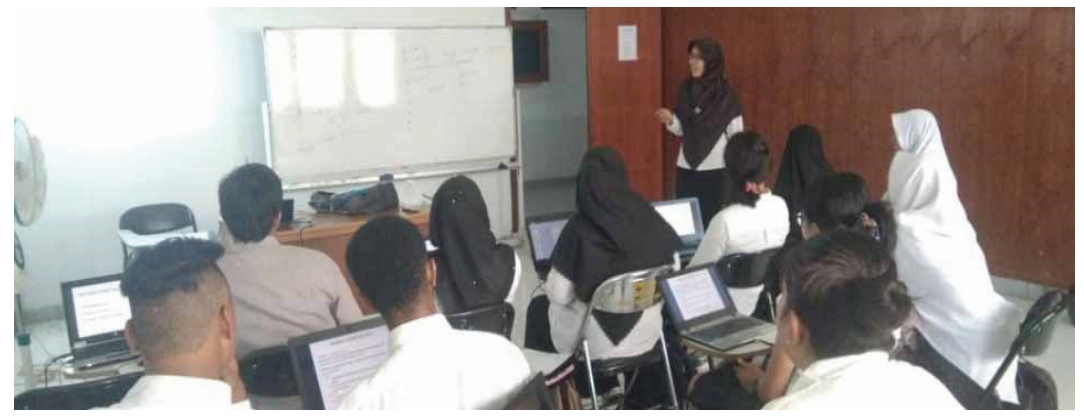

Figure 1. The lecturer gives an introduction to the KKM analysis

Model lecturers provide various problems related to KKM analysis. Students were required to be able to solve these problems. Students were divided into eight groups, each consisting of 2-3 people. Each group was given an example of KKM analysis. Then the lecturer asked several groups to present the results of the group discussion. Through this stage, students have understood how to analyze KKM to obtain KKM subjects. Then the lecturer gives the task of analyzing the KKM to practice the knowledge they have acquired. Tasks that were carried out and developed by each student were collected the following week through each student's account on Google Classroom. The Google Classroom application is supported by Gmail, drive, and docs facilities (Alverson et al., 2019). The facility helps teachers create and collect paperless tasks, including time-saving features such as the ability to automatically create Google Docs copies for each student (Alverson et al., 2019; Hooks \& Casarez, 2018).

\subsubsection{See Phase}

During the lecture process, it was seen that most groups of students actively discussed and practiced KKM analysis. They were able to determine KI, KD, and indicators and determine KKM. There were only two students who still 
looked confused, but after being allowed to ask questions and give explanations, the two students were active again. It turned out that these problematic students have a team member who was less able to work together in groups so that for the next meeting the group will be brought up and noticed the homogeneity of the group members. Cooperation was very clear, especially the number of members in a small group of 2-3 people so that each student can work effectively. The model lecturer provides group guidance so that each group can do KKM calculations correctly. Group learning can help students understand the subject matter more effectively because they can work together in their respective groups (Liu, Li, \& Zhang, 2018; Sharan, Sharan, \& Tan, 2013).

\subsection{Lesson 2}

\subsubsection{Plan Phase}

At the second meeting, the material taught is about determining the effective week. During the Plan phase, discussions were held with a team of Physics Education lecturers to improve learning devices. Lecturers prepare presentation media, examples of effective week analysis, and effective week calculation worksheets using Microsoft excel processing software.

\subsubsection{Do Phase}

At the beginning of the lecture, the model lecturer conveyed a general description of the material and provided motivation and apperception about the material analyzing the Effective Week. Students were divided into eight groups, each consisting of 2-3 heterogeneous people. Each group was given an example of an effective week analysis. Figure 2 shows the learning atmosphere where students discuss examples of effective week analysis provided by the lecturer.

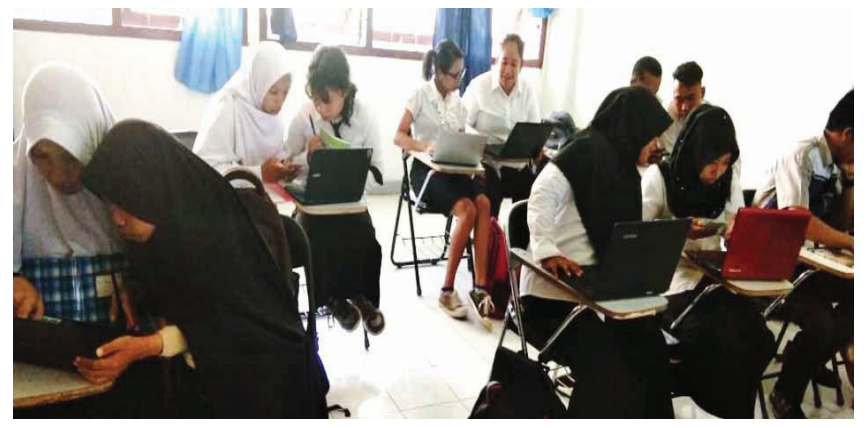

Figure 2. Lecturers provide examples of effective week analysis to be discussed with the group

The lecturer asked several groups to appear and present the results of their group discussions and prioritized groups that had never presented. Through this stage, students have understood how to analyze effective weeks. Then the lecturer gave the task of analyzing the effective week to practice the knowledge they have acquired. Tasks that were completed and developed by each student were collected the following week through each student's account on Google Classroom.

\subsubsection{See Phase}

The enthusiasm of students in asking questions. Discussions conducted by students showed an excellent academic atmosphere. Some students actively ask questions, and some students answer the questions. Model lecturer, as a facilitator in learning, provides opportunities for each student to emulate the results they get. Discussions that take place during learning were very useful because students can share their work and input from other students. Learning facilitated by the lecturer should be able to facilitate and encourage students to be creative in learning (Suryani, 2017).

\subsection{Lesson 3}

\subsubsection{Plan Phase}

At the third meeting, the material taught was about annual program preparation. During the Plan phase, discussions were held with a team of Physics Education lecturers to improve learning devices. Lecturers prepare a powerpoint presentation media, examples of annual program analysis, and annual program creation worksheets.

\subsubsection{Do Phase}

At the beginning of the lecture, the model lecturer gave a general description of the material and provided motivation and apperception about the material for the annual program preparation. Students were divided into eight groups, 
each consisting of 2-3 heterogeneous people. Each group was given examples of annual program tools. Then the lecturer asked several groups to present the results of the group discussion and prioritizing groups that had never presented. Figure 3 shows the learning atmosphere when one group explains the results of the group discussion.

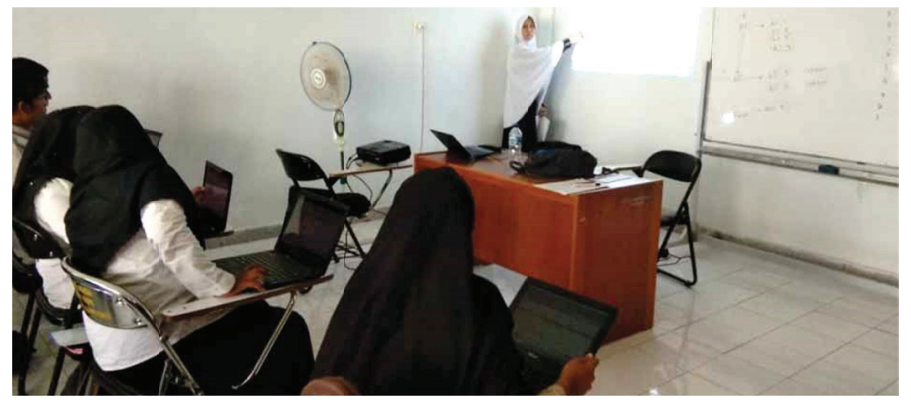

Figure 3. The lecturer asked several groups to present the results of the discussion

At the group presentation stage, students discuss how to make an annual program so that they can understand the material well. Then the lecturer assigned the task of making an annual program to practice the knowledge they have acquired. Tasks that were carried out and developed by each student were collected the following week through each student's account on Google Classroom.

\subsubsection{See Phase}

At this meeting, students appeared enthusiastic to attend the class. Students actively asked questions related to the material being studied. In group discussion activities, they were seen cooperating in working on assignments given by the model lecturers.

\subsection{Lesson 4}

\subsubsection{Plan Phase}

At the fourth meeting, the material taught was about the analysis of the semester program. During the Plan phase, discussions were held with a team of Physics Education lecturers to improve learning devices. Lecturers prepare a powerpoint presentation media, sample semester program analysis, and semester program calculation worksheets using an excel program.

\subsubsection{Do Phase}

At the beginning of the lecture, the model lecturer delivered a general description of the material and provided motivation and apperception about the material analyzing the semester program. Students were divided into eight groups, each consisting of 2-3 heterogeneous people. Each group was given examples of semester program analysis. Then the lecturer asked several groups to appear and present the results of the group discussion and prioritized groups that had never presented. Through this stage, students already understand how to analyze semester programs. Then the lecturer gave the task of analyzing the semester program to practice the knowledge they had obtained. Figure 4 shows the collaboration of students in working on the analysis tasks of the semester program.

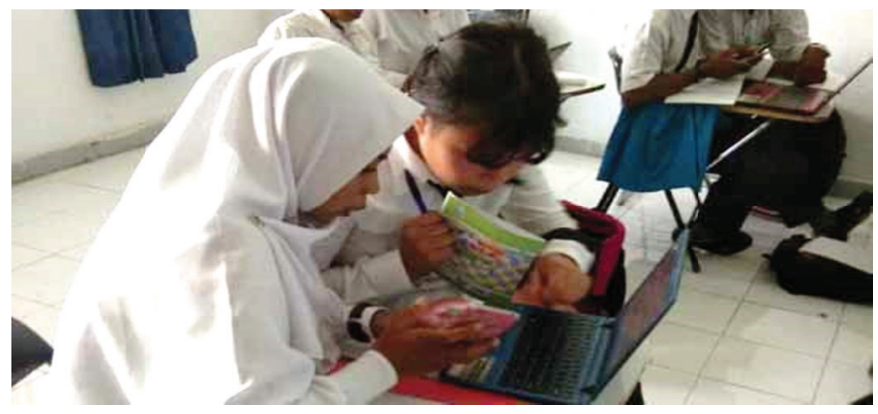

Figure 4. The lecturer gave a semester program analysis sheet to work with the group

Students work together in doing the assignments. Tasks that were completed and developed by each student were collected the following week through each student's account on Google Classroom. The lecturer can directly examine all student assignments. Students can immediately find out their grades. Figure 5 shows the appearance of online 
learning using Google Classroom.

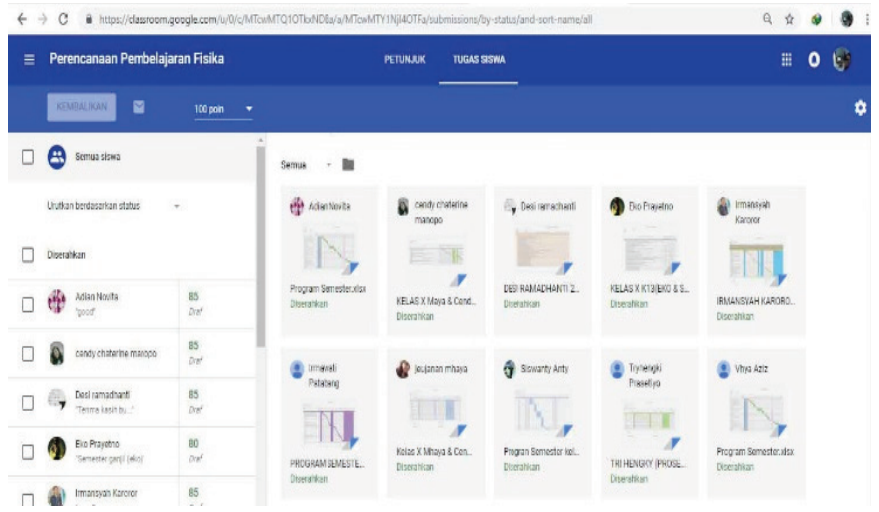

Figure 5. Google Classroom application display

\subsubsection{See Phase}

At this meeting, all students noticed the subject matter. Students who do not understand the lesson immediately ask questions. Students enjoyed taking lessons. Learning methods applied by lecturers are also appropriate to improve student-learning outcomes. PjBL learning requires students to think critically to complete the given project assignment (Bell, 2010). Project tasks completed by students have good results. This is because the learning activities continue to be improved and reflected through lesson study (Clea Fernandez, 2002).

At each meeting, an assessment of student learning outcomes was based on the given project assignment. Student assignment assessment was carried out online through the Google Classroom application. Students can find out directly the results of the assessment by the lecturer. Assessment analysis of student learning outcomes can be seen in Figure 6.

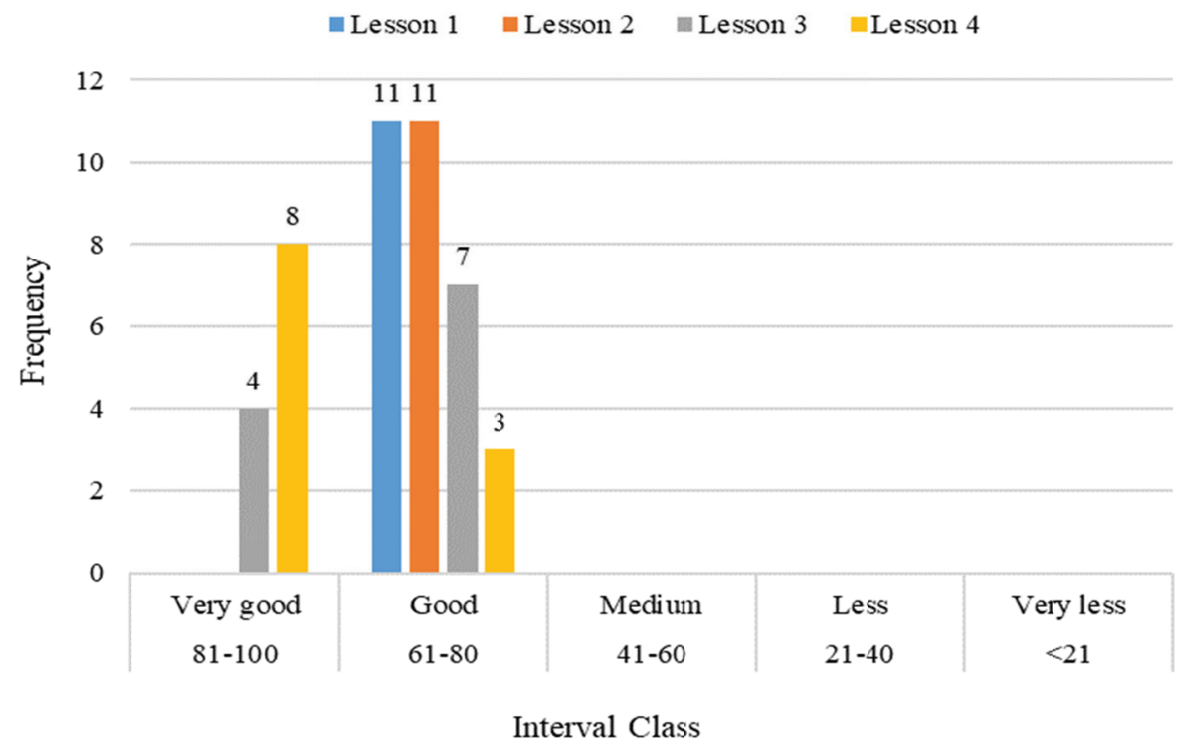

Figure 6. Analysis of student learning outcomes assessed at each meeting

Figure 6 shows that there was an increase in student learning outcomes in each assignment given at each meeting. At the first meeting, the average score was $67.8 \pm$ SD 2.4 (good) with the distribution of student learning outcomes; all of them were in a good range. The results at meeting 1 were not much different from the second meeting, which was represented by an average value of $68.6 \pm \mathrm{SD} 6.4$ (good) with the distribution of student learning outcomes, all in good categories. At the third meeting, there was an increase in the average value of $74.1 \pm$ SD 3.4 (good) with the distribution of student learning outcomes, mostly at good intervals but also at very good intervals. At the fourth meeting also experienced an increase that was obtained an average value of $75.0 \pm$ SD 6.3 (good) with the spread of 
student assessment, most of them were within the very good category, and some were in a good category. Therefore, it can be concluded that in general, PjBL assisted by E-Learning learning can improve student-learning outcomes. $\mathrm{PjBL}$ involves various stages that can improve student-learning outcomes. Through project assignments, students can involve all mental and physical, including social skills, by doing many things (Lee, Huh, \& Reigeluth, 2015; Widyaningsih \& Yusuf, 2019). PjBL was a learning approach that takes into account the mastery of concepts. Students explore, assess, interpret and synthesize information through meaningful methods (Han, Capraro, \& Capraro, 2015). Through PjBL students in conducting group investigations, this will be able to enhance their collaboration (Panasan, Nuangchalerm, \& Muang, 2010; Splichal, Oshima, \& Oshima, 2018).

At the end of the learning, students' responses to learning have been carried out. Students can provide assessment responses online through the Google Classroom application. The results of the analysis of student responses through the Ministep application were presented in Figure 7.

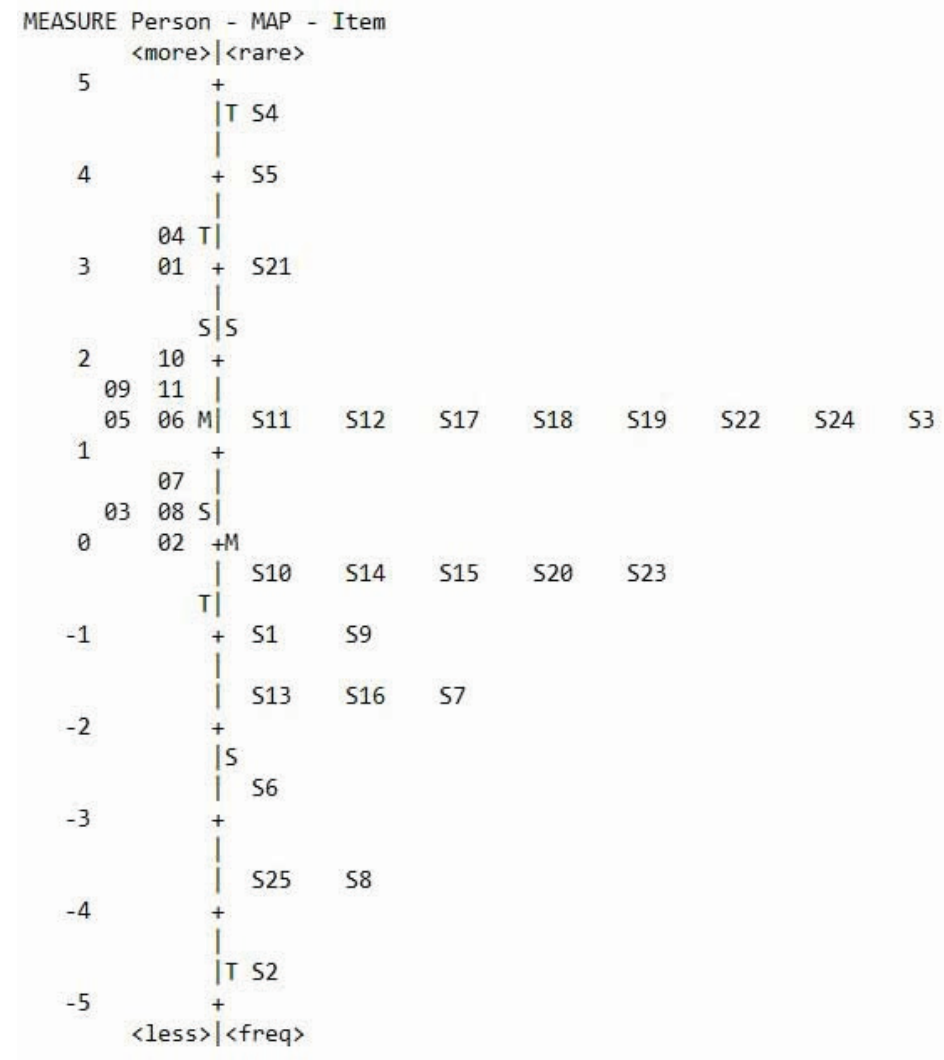

Figure 7. Student response after learning

Figure 7 shows that on the right two statements ware difficult for students to approve, namely S4 and S5. Each statement regarding the lack of delivery of material by the lecturer and the non-submission of references used in learning. Students find it difficult to approve the statement because they have been accustomed to learning directly by lecturers. The lecturer delivers all subject matter so that students were not trained in their ability to find and find their concepts. Through PjBL learning, students were required to study and complete their projects (Gülbahar \& Tinmaz, 2006). Through the help of Google Classroom, students can easily obtain information, discuss and collect tasks directly (Al-Maroof \& Al-Emran, 2018; Heggart et al., 2018). In Figure 6 the left-hand side shows that most students agree to the statement given. This shows that the learning method raises a good response for students. PjBL learning assisted by e-learning through lesson study activities encourages students' ability to be creative in completing project assignments provided through the help of information and communication technology media. The quality of learning can continue to be developed because through lesson study activities can reflect a variety of shortcomings during learning to be further improved (Saito et al., 2006). 


\section{Conclusion}

Based on the results of the research obtained, it can be concluded that the quality of learning can be improved during the implementation of PjBL learning assisted by e-learning through lesson study activities. Students were active during learning activities, and they can complete project assignments. The results of the assessment of student learning outcomes continue to increase. At the first meeting, the average score was $67.8 \pm \mathrm{SD} 2.4$ (good). The second meeting was the average value of $68.6 \pm$ SD 6.4 (good). At the third meeting, there was an increase of $74.1 \pm$ SD 3.4 (good). At the fourth meeting also experienced an increase of $75.0 \pm$ SD 6.3 (good). Therefore, it can be concluded that in general, the learning method can improve students' learning outcomes. Assessment of student responses after learning also shows a good response. It is expected that the implementation of learning like this can continue to be done to improve the quality of learning.

\section{Acknowledgments}

We would like to thank Ristekdikti for the PKP-PBMRI (lesson study) grant that was given to the University of Papua so that this activity could be carried out well. The author wishes to thank the Dean of FKIP and the Chair of LPPM University of Papua for their help and support so that this activity can be carried out smoothly.

\section{References}

Al-Maroof, R. A. S., \& Al-Emran, M. (2018). Students acceptance of google classroom: An exploratory study using PLS-SEM approach. International Journal of Emerging Technologies in Learning, 13(6), 112-123. https://doi.org/10.3991/ijet.v13i06.8275

Alverson, J., Schwartz, J., Libraries, S. S.-C. \& R., \& 2018, undefined. (2019). Authentic Assessment of Student Learning in an Online Class: Implications for Embedded Practice. Crl.Acrl.Org. Retrieved from http://crl.acrl.org/index.php/crl/article/view/16889

Barron, B. J. S., Schwartz, D. L., Vye, N. J., Moore, A., Petrosino, A., Zech, L., \& Bransford, J. D. (1998). Doing With Understanding: Lessons From Research on Problem- and Project-Based Learning. Journal of the Learning Sciences, 7(3-4), 271-311. https://doi.org/10.1080/10508406.1998.9672056

Baş, G., \& Beyhan, Ö. (2010). Effects of multiple intelligences supported project-based learning on students' achievement levels and attitudes towards english lesson. International Electronic Journal of Elementary Education, 2(3), 365-385.

Bell, S. (2010). Project-Based Learning for the 21st Century: Skills for the Future. The Clearing House: A Journal of Educational Strategies, Issues and Ideas, 83(2), 39-43. https://doi.org/10.1080/00098650903505415

Cochrane, T., Redmond, P., \& Corrin, L. (2018). Technology enhanced learning, research impact, and open scholarship. Australasian Journal of Educational Technology, 34(3), i-viii.

Fernandez, C., \& Yoshida, M. (2004). Lesson Study. New York: Routledge.

Fernandez, Clea. (2002). Learning from Japanese Approaches to Professional Development: The Case of Lesson Study. Journal of Teacher Education, 53(5), 393-405. https://doi.org/10.1177/002248702237394

Genc, M. (2015). The project-based learning approach in environmental education. International Research in Geographical and Environmental Education, 24(2), 105-117. https://doi.org/10.1080/10382046.2014.993169

Gülbahar, Y., \& Tinmaz, H. (2006). Implementing Project-Based Learning And E-Portfolio Assessment In an Undergraduate Course. Journal of Research on Technology in Education, 38(3), 309-327. https://doi.org/10.1080/15391523.2006.10782462

Han, S., Capraro, R., \& Capraro, M. M. (2015). How Science, Technology, Engineering, and Mathematics (Stem) Project-Based Learning (Pbl) Affects High, Middle, and Low Achievers Differently: the Impact of Student Factors on Achievement. International Journal of Science and Mathematics Education, 13(5), 1089-1113. https://doi.org/10.1007/s10763-014-9526-0

Heggart, K. R., Yoo, J., \& Heggart, K. (2018). Getting the Most from Google Classroom: A Pedagogical Framework for Tertiary Educators. Australian Journal of Teacher Education, 43(3), 140-153. https://doi.org/10.14221/ajte.2018v43n3.9

Heo, H., Lim, K. Y., \& Kim, Y. (2010). Exploratory study on the patterns of online interaction and knowledge co-construction in project-based learning. Computers \& Education, 55(3), 1383-1392. https://doi.org/https://doi.org/10.1016/j.compedu.2010.06.012 
Hooks, D., \& Casarez, L. (2018). Using Universal Design in Learning for Google Classroom. In E. Langran \& J. Borup (Eds.), Proceedings of Society for Information Technology \& Teacher Education International Conference 2018 (pp. 2181-2184). Washington, D.C., United States: Association for the Advancement of Computing in Education (AACE). Retrieved from https://www.learntechlib.org/p/182826

Karyadi, Sinon, I. L. S., Yusuf, I., \& Widyaningsih, S. W. (2018). Correlation Analysis between External Factors and Students 'Physics Learning Achievement. Scientiae Educatia: Jurnal Pendidikan Sains, 7(1), 42-54.

Koh, J. H. L., Herring, S. C., \& Hew, K. F. (2010). Project-based learning and student knowledge construction during asynchronous online discussion. The Internet and Higher Education, 13(4), $284-291$. https://doi.org/https://doi.org/10.1016/j.iheduc.2010.09.003

Kurniawan, R. B., Mujasam, M., Yusuf, I., \& Widyaningsih, S. W. (2019). Development of physics learning media based on Lectora Inspire Software on the elasticity and Hooke's law material in senior high school. Journal of Physics: Conference Series, 1157(032022), 1-7. https://doi.org/10.1088/1742-6596/1157/3/032022

Lee, D., Huh, Y., \& Reigeluth, C. M. (2015). Collaboration, intragroup conflict, and social skills in project-based learning. Instructional Science, 43(5), 561-590. https://doi.org/10.1007/s11251-015-9348-7

Liu, X., Li, L., \& Zhang, Z. (2018). Small group discussion as a key component in online assessment training for enhanced student learning in web-based peer assessment. Assessment \& Evaluation in Higher Education, 43(2), 207-222. https://doi.org/10.1080/02602938.2017.1324018

Panasan, M., Nuangchalerm, P., \& Muang, A. (2010). Learning Outcomes of Project-Based and Inquiry-Based Learning Activities Department of Curriculum and Instruction, Faculty of Education, Mahasarakham University, Mahasarakham 44000 Thailand. Journal of Social Sciences, 6(2), 252-255.

Riduwan. (2011). Skala Pengukuran Variabel-Variabel Penelitian. Bandung: Alfabeta.

Saito, E., Hendayana, S., Imansyah, H., Ibrohim, Isamu, K., \& Hideharu, T. (2006). Development of school-based in-service training under the Indonesian Mathematics and Science Teacher Education Project $\AA^{\circledR}$. Improving Schools, 9(1), 47-59. https://doi.org/10.1177/1365480206061999

Sarimanah, E. (2018). Developing ERIES Learning Model to Improve Students-Teacher Basic Teaching Skills Through the Implementation of Lesson Study. International Journal of Multi Disipline Science (IJ-MDS), 1(1), 29-35.

Sharan, S., Sharan, Y., \& Tan, G. C. I. (2013). The group investigation approach to cooperative learning. C. Hmelo-Silver, C. Chinn, C., A. O’Donnell, C. Chan, C.(Eds.), International Handbook of Collaborative Learning.

Skultety, L., Gonzalez, G., \& Vargas, G. (2017). Using Technology to Support Teachers' Lesson Adaptations during Lesson Study. Journal of Technology and Teacher Education, 25(2), 185-213. Retrieved from https://www.learntechlib.org/p/172139

Splichal, J. M., Oshima, J., \& Oshima, R. (2018). Regulation of collaboration in project-based learning mediated by CSCL scripting reflection. Computers \& Education, 125, $132-145$. https://doi.org/https://doi.org/10.1016/j.compedu.2018.06.003

Suryani, A. (2017). “ I am an Old Car, My Engine is not Powerful Anymore ' A Senior Teacher's Voice on His ICT Learning, Obstacles and Its"' Implications for Teachers' Development." International Journal of Pedagogy and Teacher Education (IJPTE), 1(2), 174-188. https://doi.org/10.20961/ijpte.v1i2.15000

Widyaningsih, S. W., \& Yusuf, I. (2018). Project Based Learning Model Based on Simple Teaching Tools and Critical Thinking Skills. Kasuari: Physics Education Journal (KPEJ), 1(1), 12-21.

Widyaningsih, S. W., \& Yusuf, I. (2019). Influence of RMS model (reading, mind mapping, and sharing) on student learning outcomes in school laboratory course. Journal of Physics: Conference Series, 1157(032024), 1-6.

Yusuf, I., \& Subaer. (2013). Pengembangan perangkat pembelajaran fisika berbasis media laboratorium virtual pada materi dualisme gelombang partikel di SMA Tut Wuri Handayani Makassar. Jurnal Pend. IPA Indonesia, 2(2), 189-194.

Yusuf, I., \& Widyaningsih, S. W. (2019). HOTS profile of physics education students in STEM-based classes using PhET media. Journal of Physics: Conference Series, 1157(032021), 1-5. 